\title{
PHYSICOCHEMICAL QUALITY AND MICROBIAL ACTIVITY OF DAIRY MILK WITH OZONATION
}

\author{
Dodik Suprapto $^{1)}$ 2), Lilik Eka Radiati*3), Chanif Mahdi ${ }^{4)}$, Herly Evanuarini ${ }^{3)}$ \\ 1) Doctoral Program, Faculty of Animal Science, Universitas Brawijaya, Malang 65145, Indonesia \\ ${ }^{2)}$ National Animal Husbandry Training Center, Batu, 65312, Indonesia \\ 3) Department of Animal Product Technology, Faculty of Animal Science, Universitas Brawijaya, Malang, \\ 65145, Indonesia \\ 4) Departement of Chemistry, Faculty of Mathematic and Natural Science, Universitas Brawijaya, 65145, \\ Malang, Indonesia \\ *Corresponding Email: lilik.eka@ub.ac.id
}

Submitted 4 May 2021; Accepted 9 July 2021

\begin{abstract}
The aim of this study was to evaluate the effect of ozone exposure to the physicochemical and microbial activity in dairy milk. The research material was fresh milk from dairy cows and ozone was produced by commercial ozone generator brand HANACO, production capacity up to $0.702 \mathrm{mg} / \mathrm{min}$ at $24-27^{\circ} \mathrm{C}$ with oxygen source coming from ambient air in the nature. The experiment used ozone treatments for $0,10,20$, and $30 \mathrm{~min}$ with variable of analysis such as density, protein, fat, electrical resistance, total plate count, and malondialdehyde which was analyzed using One Way Annova. The results showed that ozone treatment had no significant effect on the density, protein and fat in dairy milk, but had significant $(\mathrm{P}<0.05)$ effect on the electrical resistance, total plate count, and production of malondialdehyde. Electrical resistance and malondialdehyde were increased, while total plate count was decreased over time with the ozone exposure. Ozonation is possible to reducing yield loss on milk production that is caused by microbial activity without changing the physicochemical properties of dairy milk.
\end{abstract}

Keywords: Electrical resistance; malondialdehyde; milk ingredient; ozone; total plate count. 


\section{INTRODUCTION}

The pandemic of Covid-19 has become a serious problem for all countries in the world. All countries are competing to save their people from this expanding pandemic. Not only about health, but the national food security is also a serious problem. Milk is one of the strategic food ingredients because it can help boost the human immunity. Currently, milk production in Indonesia around of 20.92 percent from the total national milk demand, which is 4.45 million tons per year. If this condition still continues, Indonesia has the potential exposed "food trap" from developed countries which have an impact on economic stability and human welfare. Therefore, strategic steps are needed to fulfill the domestic milk consumption such as increasing dairy cow population and reducing yield loss on milk production.

Enhance the population of dairy cows is a long-term programme that needs serious attention by all elements. The short-term programme that possible to implement are minimize yield loss on milk production. The yield loss on milk production reaches $10 \%$ of total milk production which is mostly causes by adulteration, repeat incidence of mastitis during the lactation period, high contamination of microorganisms and antibiotic residues (Setyawati and Suprapto, 2017). The low awareness of farmers about the importance of Good Dairy Practices and Good Handling Practices of fresh milk has contributing to stagnant domestic milk production in the last decade.

Ozone exposure has been applied in various fields including drinking water industry, waste water management, medical equipment sterilization, textile industry, fresh food sterilization and preservation of foodstuffs. Ozone $\left(\mathrm{O}_{3}\right)$ is known as a triatomic molecule consist of three oxygen atoms, an unstable polymerized oxygen that formed from oxygen molecules dissociate into oxygen atoms which is created by the passage of air or oxygen over high energy electrodes within an ozone generator system or by ultraviolet light (Asgar, 2014; Haifan, 2017). As a high potential oxidation, ozone can be used to kill bacteria (sterilization), remove color (decolorization), remove odors (deodoration), and decompose organic compounds (degradation) without leaving chemical residues and changing the nutritional content of the product. Ozone is mainly active on the surface of bacterial cells.

The most important ozone mechanism is the sulfidrile oxidation from enzyme. This layer is the first subject to be reacted with ozone. The attack by ozone on the cell wall leads to changes in the permeability of the cells and causes lysis (Lenntech, 2020), for example ozone is an effective to therapy of clinical mastitis in dairy cows (Enginler et $a l ., 2015)$. In the modern dairy industry, ozone was applied for handling and processing, especially to recude microbial activity in milk. Sheelamary and Muthukumar (2011) reported, gaseous ozone after $15 \mathrm{~min}$ with generation rate $0.2 \mathrm{~g} / \mathrm{h}$ an effective to destroyed Listeria monocytogenes in liquid milk samples with mean viable counts 5.5 and $5.7 \log _{10} \mathrm{CFU} / \mathrm{mL}$, and Cavalcante et al. (2013) reported, ozonation with $1.5 \mathrm{mg} / \mathrm{L}$ for 15 min can removed bacterial and fungal counts up to $1 \log _{10} \mathrm{CFU} / \mathrm{mL}$. Ozonation shown by Torlak and Sert (2013) to be an effective for destroying Cronobacter sakazakii ATCC 51329 cells in milk powders, especially in dried skim milk The authors exposed whole and skim milk
*Corresponding author:

Lilik Eka Radiati

Email: lilik.eka@ub.ac.id

Departement of Animal Product Technology, Faculty of Animal Science, Universitas Brawijaya, Malang, 65145, Indonesia
How to cite:

Suprapto, D., Radiati, L. E., Mahdi, C., \& Evanuarini, H. (2021). Physicochemical Quality and Microbial Activity of Dairy Milk with Ozonation. Jurnal Ilmu dan Teknologi Hasil Ternak (JITEK), 16 (2), 117-124 
powder samples to gaseous ozone at concentrations of $2.8 \mathrm{mg} / \mathrm{L}$ or $5.3 \mathrm{mg} / \mathrm{L}$ for 0.5-2 h. Both ozone levels reduced Cronobacter counts in skim milk powder by approximately $3 \log _{10}$ orders following $120 \mathrm{~min}$ of exposure. Ozone exposure has been introducing for sterilization because it has the ability to inactivate microorganisms (Varga and Szigeti, 2016), but there is not much information about it to reduce microbial activity without changes physicochemical quality of dairy milk.

Therefore, it is important to conduct further studies about ozone therapy in dairy milk that applies for reducing microbial activity without causing changes to the physicochemical properties of milk.

\section{MATERIALS AND METHODS}

\section{Milk samples}

The study began with observations of dairy cows health and their lactation period in National Animal Husbandry Training Center-Batu. Fresh milk was obtained from 24 dairy cows that had entered the third period of lactation and selected which were indicated free of mastitis. Milking used a milking machine, filtered then collected into the milk can and analyzed in the laboratory.

\section{Ozone generator}

The ozone was produced using commercial ozonizer brand HANACO. The mechanism works of this machine are split apart some normal oxygen atoms into unstable single atoms, which bond with other oxygen molecules to form ozone by high voltage electrical charge (Lenntech, 2020). Oxygen source coming from ambient air in the nature, flowed in the generator and ozone that came out at the outlet through the hose with stone filter in the end. This system was used to distribute the generated ozone as micro bubbles in the samples, improving the ozone mass transfer and homogeneity.

\section{Ozonation process}

The 1,000 mL of milk was stirred until homogeneous in the measuring cup. Install the stone filter at the end of the ozone generator output hose, put it in the milk, close the container, then turn on the ozonizer. The ozone concentration in a min was monitored to reach $0.702 \mathrm{mg} / \mathrm{L}$ (Sari and Hadi, 2014). Ozonation was carried out at room temperature $\left(24-27^{\circ} \mathrm{C}\right)$ for $0 \mathrm{~min}$ (P1), $10 \mathrm{~min}$ (P10), $20 \mathrm{~min}$ (P20) and $30 \mathrm{~min}$ (P30) in a closed container, equivalent with $0 \mathrm{mg} / \mathrm{L}(\mathrm{P} 1), 7.02 \mathrm{mg} / \mathrm{L}$ (P2), $14.04 \mathrm{mg} / \mathrm{L}$ (P3 and $21.06 \mathrm{mg} / \mathrm{L}(\mathrm{P} 4)$ dosage of ozone.

\section{Physicochemical and microbial activity assay}

The milk samples were evaluated according physicochemical and microbial activity parameters in triplicate. Density, protein and fat were detected by Lactoscan MCC. Electrical resistance was detected by Hand-held EC Meter Draminski Mastitis Detector, Poland (Galfi et al., 2015). The results of milk electrical resistance were interpreted according to the manufacturer's instructions (Table 1).

Table 1. Interpretation of results obtained with Draminski Mastitis Detector, Poland

\begin{tabular}{ll}
\hline \multicolumn{1}{c}{ Readings } & \multicolumn{1}{c}{ Interpretation of results } \\
\hline Above 300 units & $\begin{array}{l}\text { The milk sample is of high quality and is healthy. The incidence } \\
\text { of subclinical mastitis is very low }\end{array}$ \\
\hline $\begin{array}{l}\text { Between 250 and 300 } \\
\text { units }\end{array}$ & $\begin{array}{l}\text { A progressively increasing incidence of subclinical infection as } \\
\text { readings decrease }\end{array}$ \\
\hline Below 250 units & $\begin{array}{l}\text { This is an indication of a rapid increase in the severity of } \\
\text { infection as subclinical mastitis progresses to clinical states. } \\
\text { This is typified by somatic cells present rising from less than 1 } \\
\text { million up to many millions }\end{array}$ \\
\hline
\end{tabular}


Total plate count was analyzed with Indonesia Law in the Total Plate Count Analysis (SNI 01-2332.3-2006), and production of malondialdehyde was analyzed with spectrophotometer $532 \mathrm{~nm}$ for thiobarbituric (Mahdi et al., 2017) that modified. All data was analyzed using One Way Annova by IBM SPSS Statistics version 24.0 for Windows.

\section{RESULTS AND DISSCUSION}

\section{Result}

Figure 1 presents the average results of the physicochemical properties ie. density, protein, and fat evaluated on dairy milk before and after ozonation. Ozone therapy did not have a significant difference $(\mathrm{P}>0.05)$ to the density, protein and fat of dairy milk. Dairy milk without ozone exposure has density of $1.0285 \mathrm{~g} / \mathrm{cm}^{3}$, only difference of $0.0003 \mathrm{~g} / \mathrm{cm}^{3}$ when compared with longest ozone exposure in $30 \mathrm{~min}$. The protein content in this research ranged from 3.38 up to 3.40 percent, and the milk fat content range from 4.40 up to 4.57 percent. This results still above the minimum threshold of Indonesian law in the Quality Requirements for Fresh Milk (SNI 01-31412011) for minimum density, protein and fat are $1.027 \mathrm{~g} / \mathrm{cm}^{3}, 2.8$ percent and 3.0 percent.

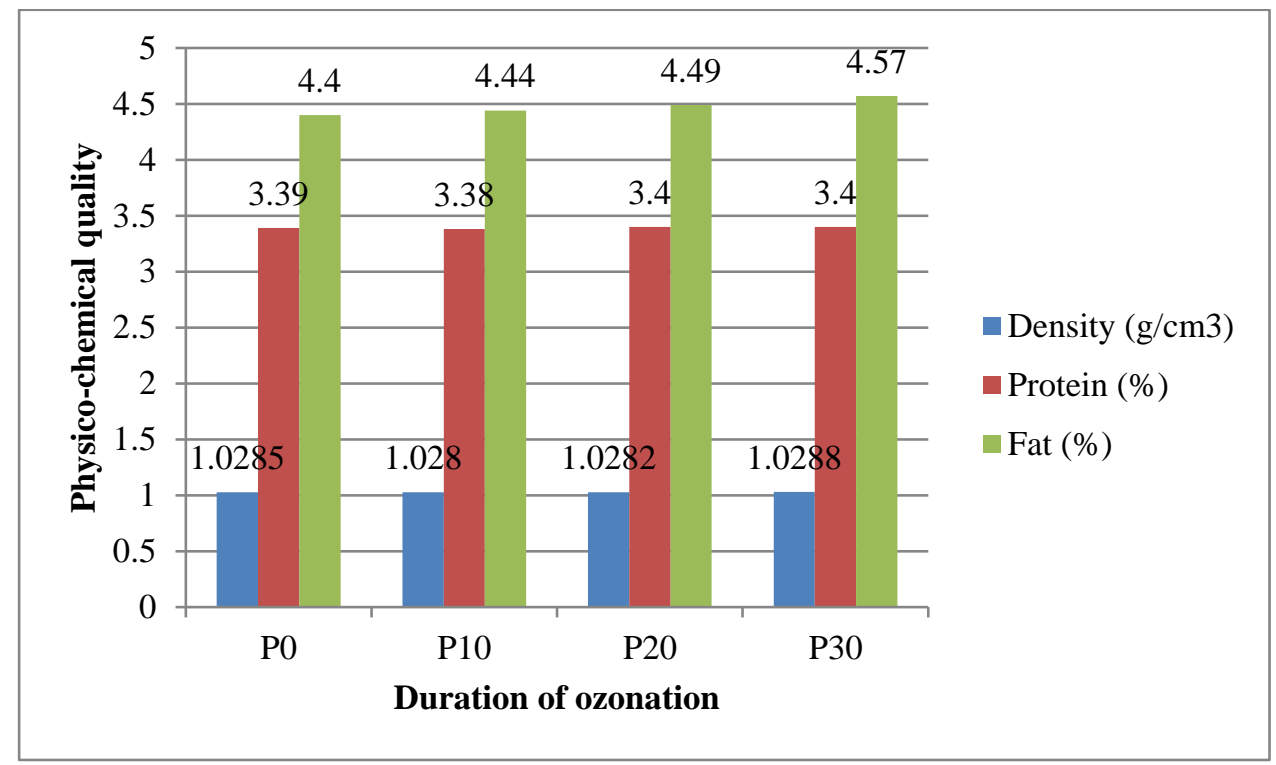

Figure 1. The average of physicochemical properties of dairy milk with ozonation

Table 2. The average of microbial activity of dairy milk with ozonation

\begin{tabular}{cccc}
\hline Treatments & $\begin{array}{c}\text { Electrical Resistance } \\
\text { (units) }\end{array}$ & $\begin{array}{c}\text { Total Plate Count } \\
(\mathrm{CFU} / \mathrm{mL})\end{array}$ & $\begin{array}{c}\text { Malondialdehyde } \\
(\mu \mathrm{g} / \mathrm{mL})\end{array}$ \\
\hline P0 & $376,67 \pm 3,33^{\mathrm{a}}$ & $0,15 \times 10^{6 \mathrm{a}}$ & $0,0137 \pm 0,0036^{\mathrm{a}}$ \\
P10 & $376,67 \pm 13,33^{\mathrm{a}}$ & $0,13 \times 10^{6} \mathrm{ab}$ & $0,1941 \pm 0,0367^{\mathrm{b}}$ \\
P20 & $386,67 \pm 3,33^{\mathrm{ab}}$ & $0,12 \times 10^{6} \mathrm{ab}$ & $0,2234 \pm 0,0730^{\mathrm{b}}$ \\
P30 & $400,00 \pm 10,00^{\mathrm{b}}$ & $0,10 \times 10^{6} \mathrm{~b}$ & $0,2809 \pm 1,1060^{\mathrm{b}}$ \\
\hline
\end{tabular}

Remarks : *Mean values within a column followed by the different letters are significantly different at $\mathrm{p}<0.05$ according to Duncan's Multiple Range Test.

$* \mathrm{~ns}=$ not significant

The average results of microbial activity in dairy milk ie. electrical resistance, total plate count, and production of malondialdehyde are shown in Table 2 . The result showed that ozone therapy had significant $(\mathrm{P}<0.05)$ to the electrical conductivity, total plate count, and production of malondialdehyde. Electrical 
resistance and malondialdehyde were increased, while total plate count was decreased over time with the ozone exposure. Ozonation for 0 and $10 \mathrm{~min}$ produced a constant electrical resistance of 376.67 units, however ozonation for 20 and 30 min showed an increase of 386.67 and 400 units. The results of the total plate count, ozone exposure are effective for reduce the total plate count in milk. The total plate count of fresh milk without ozonation reached $0.15 \times 10^{6} \mathrm{CFU} / \mathrm{mL}$, and after ozonation for 10,20 and $30 \mathrm{~min}$, the total plate count decreased up to $0.13 \times 10^{6} \mathrm{CFU} / \mathrm{mL}, 0.12 \times 10^{6} \mathrm{CFU} / \mathrm{mL}$, and $0.10 \times 10^{6} \mathrm{CFU} / \mathrm{mL}$. Observations continued to the production of malondialdehyde as an indicator damage to the cell membrane of microorganism, the control sample reached $0.0137 \mu \mathrm{g} / \mathrm{mL}$, after ozonation for 10,20 and $30 \mathrm{~min}$, production of malondialdehyde reached $0.1941 \mu \mathrm{g} / \mathrm{mL}, 0.2234 \mu \mathrm{g} / \mathrm{mL}$ and $0.2809 \mu \mathrm{g} / \mathrm{mL}$. There is a correlation between increased of the electrical resistance and malondialdehyde with the decreased of total plate count in dairy milk samples after ozonation.

\section{Discussion}

The density of dairy milk depending on the lactation period, milking, feeding and breeding. While the quality of milk is influenced by milk adulteration (Asefa et al., 2019; FAO, 2020). Based on the results of the research, the density of dairy milk sample, both milk control and milk with ozonation treatment, has a density that still in FAO (1.026-1.034 g/ $\left.\mathrm{cm}^{3}\right)$ and Indonesian law standards $\left(1,028 \mathrm{~g} / \mathrm{cm}^{3}\right)$. Temperature changes have an influence on the density assessment, at low temperatures the viscosity will be higher, it causes the density of milk will increase and vice versa (Sukmawati, 2014). Ozone exposure does not involve changes in temperature so it is possible that there is no change in density of milk before and after ozonation. Ozonation technology does not leave chemical residues on exposed food products because they are unstable and quickly turn into environmentally friendly non-toxic compounds (Hamodah et al., 2019). The results of this study are in line with previous research conducted by Cavalcante et al. (2013) concluded that exposure to ozone as much as $1.5 \mathrm{mg} / \mathrm{L}$ for $15 \mathrm{~min}$ did not cause changes in the physicochemical properties of fresh milk.

Ozonation does not cause heat exposure and leaves harmful residues in the milk. The absence of temperature changes will minimize the protein denaturation so that the quality of fresh milk can be maintained during ozonation. The complexity of the compounds in milk involved lower ozonation performance due to molecular resistance from the milk matrix. Decreasing $\mathrm{pH}$ can protonate nitrogen-based groups which make it less reactive to electrophilic reactions with ozone molecules (Chelme-Ayala et al., 2010). Protonated amina groups are significantly less reactive to ozone oxidation, therefore ozone will attack other groups such as aromatic rings and sulfur atoms. Ozone decomposition increases with increasing $\mathrm{pH}$ and results in the production of hydroxyl radicals $(\bullet \mathrm{OH})$. Oxidation through hydroxyl radicals is less likely to be the dominant decomposition mechanism because milk has an acidic $\mathrm{pH}$ close to neutral (Alsager et al., 2018).

This condition causes protein in milk to be relatively resistant to ozonation treatment. Different with the milk processing of by heating. Wulandari et al. (2017) reported, the pasteurization process can reduce milk protein levels by up to 10.49 percent. The temperature and duration of heating influence the degraded of protein content because of denaturation. Qian et al. (2017) stated that the degree of whey protein denaturation increased from 27.31 percent to 46.50 percent gradually at over time $75^{\circ} \mathrm{C}$ and increased from 65.30 percent to 100 percent at $85^{\circ} \mathrm{C}$ at pasteurization for 10,20 and $30 \mathrm{~min}$. There is a tendency to increase milk fat after receiving ozonation treatment. Fresh milk without ozone exposure has a fat content of 4.40 percent, and after ozonation 
at 10, 20 and $30 \mathrm{~min}$, the results of milk fat content are 4.44 percent, 4,49 percent and 4.57 percent. The contact time and temperature of the ozonation greatly affect to the concentration of ozone that dissolved in milk, and the opportunity to separate fat bonds with proteins will be higher. Ozone is a strong oxidizing agent (Varga and Szigeti, 2016), which allows fat as a protector of milk protein to separate from casein micelles. The use of ozone genarator with the air bubble method will increase the homogeneity and concentration of ozone dissolved in milk (Cavalcante et al., 2013). This condition cause the milk fat will be evenly distributed throughout the surface of the milk and fat content will be higher when analyzed.

According to Galfi et al. (2015), as a results of the damage to the udder tissue, concentration of lactose and potassium decrease, and concentration of sodium and chloride increase. Concentration of sodium and chloride ions increases in milk from infected quarters which leads to increased electrical resistance of milk. There is an increased of electrical resistance after ozonation. These indicates that the milk is healthier and has a lower number of microbial contamination, both caused by bacteria that cause mastitis or crosscontamination. Ozonation improving the quality of the sample milk and reducing risk of subclinical mastitis incidence caused by microbial activity. Ozonation is effective for bacteriological and clinical recovery and can be an alternative antibiotic treatment in cases of acute clinical mastitis caused by coagulase negative Staphylococci, but not effective for the treatment of mastitis caused by Streptococci and Candida sp. (Sertkol et al., 2018). Somatic cell count gradually decreases with the time of treatment using ozonation so that it can be used as an alternative treatment for sub-clinical mastitis (Enginler et al., 2015). The total plate count results showed that all samples were in accordance with Indonesian law (SNI 01-3141-2011) which had a maximum total plate count of $1 \times 10^{6} \mathrm{CFU} / \mathrm{mL}$.
These indicates that fresh milk comes from healthy cows and obtain good handling to minimized cross-contamination. Based on the average result, ozonation had been effective to reducing total plate count in milk samples. The decrease of total plate count caused by ozone because it is a strong oxidizer that can oxidize microbial enzymes and nucleic acids, damage macromolecular polysaccharide polymers including DNA, RNA, protein, and fatty acids, thereby impairing metabolism and microbial reproduction. Ozone can deactivate the cell membrane or react on the outer membrane of lipoproteins and internal fat polysaccharides to produce cell distortion and to dissolve genes, phages, mycoplasma and other elements (Lenntech, 2020). The decrease of total plate count in this study is in line with previous studies conducted by Cavalcante et al., (2013). The number of Enterobactereaceae, aerobic mesophilic, psychrotrophic, yeast and mold, as well as Staphylococcus sp. For non-ozonated milk, the sequences were $2.39 ; 4.18 ; 3.01 ; 2.70$; $2.16 \log _{10} \mathrm{CFU} / \mathrm{mL}$.

Ozonation treatment for 5 min was not able to reduce the number of milk microbes, but ozonation for $10 \mathrm{~min}$ was able to significantly reduce microbial contamination $\quad(\mathrm{P}<0.05), \quad$ namely Enterobacteriaceae $(0.59 \mathrm{log})$, yeast and mold $(0.25 \mathrm{log})$ and Staphylococcus sp. $(0.59 \mathrm{log})$. The ozonation treatment for $15 \mathrm{~min}$ was able to increase the inactivation of the evaluated microbes, namely 0.96 ; $0.60 ; 0.13 ; 0.48$ and $1.02 \log 10 \mathrm{CFU} / \mathrm{mL}$ for Enterobacteriaceae, mesophilic aerobic, psychrotrophic, yeast and mold, and Staphylococcus sp. Ozonation using the air bubble method can be adopted as a preliminary process which aims to reduce the amount of microoranism contamination in fresh milk during handling, without prejudice to the heating procedure in the processing stage. Based on statistical analysis, there was an increase production of malondialdehyde after ozonation. Duration of ozonation had effect to production of free radical concentration, so that it has a positive 
correlation with production of malondialdehyde and cell membrane damage. The damage of cell membranes and miticondria, high levels of ROS and free radicals, the damage of enzyme and coenzyme systems in oxidative phosphorylation, beta oxidation cycle and decreased production of ATP and acidosis can lead to death cells both by necrosis and apoptosis (Mahdi, 2016). These results in line with Mahdi and Aulaniam (2011), various doses of formaldehyde as a source of free radicals in rats diet significantly increase production of malondialdehyde, which is closely related with cell membrane damage.

In this case, what makes the difference is the process of free radical formation between ozone and formaldehyde in damaging cell membranes. Formaldehyde exposure takes place in the body, so that the free radicals produced will have an impact on living cells, while ozone exposure takes place outside the body and is unstable, so that it will only attack specific cell membranes, especially microbes in milk and after the withdrawal time ends, the product is safe again without leaving free radicals (Mahdi and Aulaniam, 2011; Inal et al., 2011). The longer exposure of ozone will increase the production of free radicals formed during ozone decomposition. This condition will increase oxidative stress and the interaction between free radicals and PUFAs in fresh milk, which it has an impact on increasing lipid peroxidation, thereby increasing production of malondialdehyde and damaging cell membranes. Ozone therapy are effective to removed contaminant from pathogenic bacteria without changes the physicochemical of dairy milk. The risk of losses on milk production due to microbial activity can be minimized.

\section{CONCLUSION}

The results of this study showed that ozone bubbling for $30 \mathrm{~min}$ is effective to push damage on cell membranes of microorganism and reduce total plate count without changes the physicochemical properties of dairy milk. The risk of losses on milk production due to microbial activity can be minimized.

\section{ACKNOWLEDGMENT}

The authors are grateful to Indonesia Agency of Agriculture Human Resource Development and Extension, Ministry of Agriculture for financial support.

\section{REFERENCES}

Alsager, O. A., Alnajrani, M. N., Abuelizz, H. A., \& Aldaghmani, I. A. (2018). Removal of antibiotics from water and waste milk by ozonation: kinetics, byproducts, and antimicrobial activity. Ecotoxicology and Environmental Safety, 158, 114-122. https://doi.org/ 10.1016/j.ecoenv.2018.04.024

Asefa, Z., \& Teshome, G. (2019). Physical properties and chemical compositions of raw cow milk in milk shades around addis ababa, Ethiopia. Journal of Natural Sciences Research, 9(19), 3337. https://doi.org/10.7176/JNSR/9-19-04

Asgar, A. (2014). Iptek Hortikultura. In teknologi ozonisasi untuk mencuci sayuran (pp. 10-12). Balai Penelitian Tanaman Sayuran.

Cavalcante, M. A., Leite Júnior, B. R. de C., Tribst, A. A. L., \& Cristianini, M. (2013). Improvement of the raw milk microbiological quality by ozone treatment. International Food Research Journal, 20(4), 2017-2021.

Chelme-Ayala, P., El-Din, M. G., \& Smith, D. W. (2010). Kinetics and mechanism of the degradation of two pesticides in aqueous solutions by ozonation. Chemosphere, 78(5), 557562. https://doi.org/10.1016/j.chemo sphere.2009.11.014

Enginler, S. Ö., Sabuncu, A., Kahraman, B. B., Koçak, Ö., Yildar, E., \& Güzel, Ö. (2015). Comparison of intramammary ozone administration doses in dairy 
cows with clinical mastitis. Acta Scientiae Veterinariae, 43(1), 1-7.

Galfi, A., Radinovic, M., Milanov, D., Bobos, S., Pajic, M., Savic, S., \& Davidov, I. (2015). Electrical conductivity of milk and bacteriological findings in cows with subclinical mastitis. Biotechnology in Animal Husbandry, 31(4), 533-541. https://doi.org/10.2298/BAH1504533G

Haifan, M. (2017). Review kajian aplikasi teknologi ozon untuk penanganan buah, sayuran dan hasil perikanan. Jurnal IPTEK, 1(1), 15-21.

Hamodah, S. E., Andoyo, R., Mardawati, E., \& Ibrahim, A. I. (2019). A review on influence of ozone and pasteurization on physicochemical properties, microbiology, and stability of milk. Journal of Engineering Science Invention, 8(1), 10-15.

İnal, M., Dokumacioglu, A., Özcelik, E., \& Ucar, O. (2011). The effects of ozone therapy and coenzyme Q10 combination on oxidative stress markers in healthy subjects. Irish Journal of Medical Science, 180(3), 703-707. https://doi.org/10.1007/s11 845-011-0675-7

Lenntech, B. V. (2020). Ozone Desinfection Mechanism. www.lenntech.com

Mahdi, C. (2016). Antioksidan, ROS dan Radikal Bebas, serta Dasar Imunologi. Jaya Mayantara.

Mahdi, C, \& Aulaniam. (2011). Suplementasi yogurt pada tikus (Rattus norvegicus) yang terpapar formaldehid dalam makanan terhadap aktivitas antioksidan enzimatis jaringan hepar. NATURAL B, 1(2), 182-187.

Mahdi, Chanif, H., U., \& Padaga, P. (2017). Fermented goat milk supplementation in rats hypercholesterolmic on malonyldialdehyde and description of liver histopathology. Indonesian Journal of Cancer Chemoprevention, 8(1), 1-8. https://doi.org/10.14499/ indonesianjcanchemoprev8iss1pp1-8 Muthuchamy, M., Sheelamary, M., \& Muthukumar, M. (2011). Effectiveness of ozone in inactivating Listeria monocytogenes from Milk Samples. $J$ Young Researchers, 1(3), 40-44.

Qian, F., Sun, J., Cao, D., Tuo, Y., Jiang, S., \& Mu, G. (2017). Experimental and modelling study of the denaturation of milk protein by heat treatment. Korean Journal for Food Science of Animal Resources, 37(1), 44-51. https://doi. org/10.5851/kosfa.2017.37.1.44

Sertkol, C., Saribay, A. M. K., \& Cantekin, B. Z. (2018). Recovery effect of intramammary ozone therapy for acute clinical mastitis in dairy cows. Journal Veterinir Health Science, 32(3), 185-190.

Setyawati, E., \& Suprapto. (2017). Reducing losses of milk production. Seminar of Improving the Income of Small and Medium Scale Farmers in Oic Member State through Reducing Losses of Livestock Production, 24-25.

Sukmawati, N. M. . (2014). Faktor-Faktor yang Mempengaruhi Susunan dan Keadaan Air Susu. Fakultas Peternakan Universitas Udayana.

Torlak, E., \& Sert, D. (2013). Inactivation of Cronobacter by gaseous ozone in milk powders with different fat contents. International Dairy Journal, 32(2), 121-125. https://doi.org/10.1016/j.ida iryj.2013.05.013

Varga, L., \& Szigeti, J. (2016). Use of ozone in the dairy industry: A review. International Journal of Dairy Technology, 69(2), 157-168. https:// doi.org/10.1111/1471-0307.12302

Wulandari, E., Suryaningsih, L., Pratama, A., \& Putra, D. S. (2016). Karakteristik fisik, kimia dan nilai kesukaan nugget ayam dengan penambahan pasta tomat. Jurnal Ilmu Ternak, 16(2), 95-99. 